\title{
DOWNTOWN REVITALIZATION STRATEGY REPORT FOR GLENROCK, WY
}

\author{
A Master's Project presented to \\ the Faculty of California Polytechnic State University, \\ San Luis Obispo
}

\author{
In Partial Fulfillment \\ of the Requirements for the Degree \\ Master of City and Regional Planning
}

by

Mary E. Phillips

November, 2011 
(C) 2011

Mary E. Phillips

ALL RIGHTS RESERVED 
COMMITTEE MEMBERSHIP

TITLE: Downtown Revitalization Strategy Report for Glenrock, WY

AUTHOR: Mary E. Phillips

DATE SUBMITTED: $\quad$ November, 2011

COMMITTEE CHAIR: Michael Boswell, Associate Professor

COMMITTEE MEMBER: Paul Wack, Professor

COMMITTEE MEMBER: Nore V. Winter, Principal Winter \& Company 


\section{ABSTRACT \\ Downtown Revitalization Strategy Report for Glenrock, WY \\ Mary E. Phillips}

The following project submitted for the Master of City and Regional Planning Professional Project is the Downtown Revitalization Strategy Report for Glenrock, WY completed November 25, 2009.

At the onset of the project, the Town of Glenrock, WY was recognized as an Aspiring Main Street Community, and sought guidance to become a Certified Main Street Community. This Strategy Report was prepared to provide an implementation plan for revitalization of the downtown following the Main Street Approach, as well as for achievement of a Certified Main Street Community status by the year 2014 .

The project included an interactive process, directly involving key representatives and stakeholders in the community. This included a public workshop and on-site strategy sessions with Town staff and the Glenrock Downtown Development Committee. The Strategy Report includes a basic assessment of existing conditions in downtown Glenrock based on information gathered at these meetings. From this initial assessment, issues, goals and objectives for downtown were identified. An overall strategy was then developed, in accordance with the Main Street Approach, which outlines the plan of action for the downtown revitalization and Main Street certification.

The implementation section of the plan then takes the identified actions and prioritizes them based on a 5-year implementation schedule. The development and prioritization of these actions was based on the following factors:

- Requirements for the Wyoming Main Street Community certification status

- Community goals for development in the downtown

- Feasibility of implementation of plan components

- Access to resources (of all types) for implementation

- Players in the implementation of the plan

The result of this methodology was a plan that addressed the community's needs, with an implementation program specifically tailored for the community's available resources. 


\section{TABLE OF CONTENTS}

CHAPTER

PAGE

INTRODUCTION

Background

How this Report is Organized 1

The Main Street Four-Point Approach 2

ORGANIZATION 3

Organization Existing Conditions \& Assets 3

Organization Issues $\quad 4$

$\begin{array}{ll}\text { Organization Opportunities } & 5\end{array}$

$\begin{array}{ll}\text { Organization Actions } & 5\end{array}$

$\begin{array}{ll}\text { PROMOTION } & 10\end{array}$

Promotion Existing Conditions \& Assets 10

$\begin{array}{ll}\text { Promotion Issues } & 11\end{array}$

$\begin{array}{ll}\text { Promotion Opportunities } & 11\end{array}$

$\begin{array}{ll}\text { Promotion Actions } & 12\end{array}$

$\begin{array}{ll}\text { DESIGN } & 13\end{array}$

Design Existing Conditions \& Assets 13

$\begin{array}{ll}\text { Design Issues } & 14\end{array}$

$\begin{array}{ll}\text { Design Opportunities } & 15\end{array}$

$\begin{array}{ll}\text { Design Actions } & 16\end{array}$ 
$\begin{array}{ll}\text { ECONOMIC RESTRUCTURING } & 19\end{array}$

Economic Restructuring Existing Conditions \& Assets 19

Economic Restructuring Issues $\quad 20$

Economic Restructuring Opportunities 20

Economic Restructuring Actions $\quad 21$

$\begin{array}{ll}\text { IMPLEMENTATION } & 22\end{array}$

$\begin{array}{ll}\text { Implementation Table } & 22\end{array}$

$\begin{array}{ll}\text { BIBLIOGRAPHY } & 25\end{array}$ 


\section{Introduction}

The town of Glenrock is recognized as an Aspiring Main Street community, which is the entry-level of the State's three-tiered program. They are nearing completion of their first year in the Wyoming Main Street program and are seeking to achieve the Certified Main Street level. The intermediate step is the Affiliate Level. This report begins by outlining the existing conditions in Glenrock. It then establishes an action plan to revitalize downtown Glenrock and achieve Certified Main Street status by the year 2014 .

\section{Background}

This project included a basic assessment of existing conditions in downtown Glenrock, including a public meeting, and an on-site strategy session with town staff and the Glenrock Downtown Development Committee. From this assessment, issues, goals and objectives for downtown were identified. An overall strategy was then developed in accordance with the Main Street Approach, which outlines the plan of action for the downtown revitalization.

\section{How this Report is Organized}

The main body of this report reflects the four points of the Main Street program and is followed by an implementation section. The discussion of each of the four points provides an evaluation of existing conditions in Glenrock, including assets, issues and opportunities, as well as identifies a series of relevant actions. The implementation section then takes these actions and prioritizes them based on a 5-year implementation schedule. 


\section{The Main Street Four-Point Approach}

Throughout the nation, communities use the Main Street approach to revitalize their traditional commercial districts. The Main Street Four-Point Approach is a community-driven, comprehensive strategy used to revitalize downtown and neighborhood business districts. It addresses a wide variety of issues and problems that challenge traditional business districts. The four points of the Main Street approach, Organization, Promotion, Design and Economic Restructuring, work together to build a sustainable and complete community revitalization effort. 


\section{Organization}

According to the National Trust Main Street program, organization "involves getting everyone working toward the same goal and assembling the appropriate human and financial resources to implement a Main Street revitalization program." Key organization roles include a program director, a governing board and an operating standing committees of volunteers.

\section{Organization Existing Conditions \& Assets}

Several Glenrock organizations exist which may play key roles in the revitalization of downtown. These volunteer groups are among Glenrock's strongest assets.

\section{Primary Players.}

- Wyoming Main Street

- The Town of Glenrock

- Glenrock Historic Commission

- Glenrock Downtown Development Committee (GDDC) (Main Street Committee)

- Chamber of Commerce

- Glenrock Economic Development Commission (GEDC)

- Revitalization Association for Main Street (RAMS)

\section{Other Supporting Players.}

- Garden Club

- Town Schools 
- Boys and Girls Club

$\cdot 4-\mathrm{H}$

- FCC

\section{Potential Players or Groups of Players.}

- Downtown Business Owners

- Downtown Property Owners

- Individual Citizens

- Energy Companies

\section{Organization Issues}

\section{Establishing a Common Vision.}

Each group of key players has their own priorities and vision. There is no coordinated vision between the groups, nor does a clear distinction or roles between the groups exist.

\section{Lack of Coordinated Efforts Between Groups.}

Though there have been successful cooperative events hosted by key player groups, there is still an overall need for coordinated efforts geared towards the overall Main Street Program objectives.

\section{Limited Fundraising Sources.}

As a small community Glenrock has limited sources for fundraising. When several groups with similar goals ask the community for donations they may feel that it becomes excessive. 


\section{Obtaining Volunteers.}

The existing volunteers consist of the same primary group of citizens. An expansion of the volunteer base, both as individuals and groups, is needed.

\section{Reaching Business Owners.}

While several business owners support the main street objectives, there are many that have either not been introduced to the program or have yet to participate in it.

\section{Organization Opportunities}

\section{Coordinated Strategies Between Groups.}

The existing key players are a large asset to the Town. If they establish a means to coordinate successfully they can be much more effective in achieving the community's goals.

\section{Organization Actions}

\section{Main Street Actions:}

01: Establish paid Executive Director Position (at least part-time). The Wyoming Main Street program requires a paid staff person for Affiliate level Communities, at least at a part-time level.

\section{O2: Confirm Committee Structure/Roles.}

The GDDC should clearly define its structure, including member and subcommittee roles. A viable organizational structure is required by Wyoming Main Street to achieve Affiliate Community status. 


\section{O3: Attend National Main Street Annual Conference.}

The Wyoming Main Street program requires attendance at the National Main Street annual conference for Affiliate level Communities.

\section{4: Attend Basic Training Workshops.}

Attendance at quarterly training workshops for the Program manager and board members is required by Wyoming Main Street to achieve Affiliate Community status.

\section{5: $\quad$ Attend Quarterly Manager Training Workshops.}

Attendance at quarterly manager training workshops is required by Wyoming Main Street to achieve Affiliate Community status.

\section{6: Secure Local Government Funding Source.}

The Wyoming Main Street program requires financial and/or in-kind support from local government to achieve Affiliate Community status.

\section{7: Secure Main Street Affiliate Status.}

Actions 01-06 are requirements of the Wyoming Main Street program for Affiliate Communities. The Town of Glenrock has one year left as an Aspiring Main Street Community in which to meet these requirements and apply for Affiliate status.

\section{8: Develop Vision and Mission Statements.}

The development of vision and mission statements relevant to community conditions is required by the Wyoming Main Street program to achieve Certified Community status. 


\section{9: Develop Comprehensive Main Street Work Plan.}

The Wyoming Main Street program requires a comprehensive Main Street work plan to achieve Certified Community status.

\section{0: Develop Operating Budget Plan.}

An operating budget is a requirement of the Wyoming Main Street program for a Certified Community.

011: Secure National Trust Main Street Network membership.

A National Trust Main Street Network membership is required by the Wyoming Main Street program for a Certified Community.

\section{2: Secure Main Street Manager Certification.}

A Certified Main Street Manager or training program for the manager is required by the Wyoming Main Street program for a Certified Community.

\section{3: Attend All Managers Meetings.}

The Wyoming Main Street program requires attendance at all managers' meetings by the Program Manager for a Certified Community.

\section{4: Secure Main Street Certified Status.}

Actions $08-013$ are requirements of the Wyoming Main Street program for Certified Communities. The Town of Glenrock will have three years as an Affiliate Main Street Community in which to meet these requirements and apply for Certified status. 


\section{Key Player Organization Actions:}

\section{5: Confirm Roles of Key Players in Work Plan.}

Clearly define the role of each group of key players, as well as how their roles fits into the overall work plan.

016: Establish an Annual "Retreat" for All Downtown Improvement Key Players.

An annual retreat for key players will help to clarify priorities and roles for each group and encourage communication and cooperation among them. The retreat should include progress checks, a review of roles, the celebration of success of the past year and the setting of goals for the next year.

017: Establish Coordinated Fundraising for Groups and Committees.

By combining efforts for fundraisers, the Main Street key player groups can make fundraising more efficient. This will also put less strain on the community for donations by limiting the number of times they are asked for support.

\section{General Organization Actions:}

\section{8: Provide an Annual Report to Council.}

An annual report by the program manager to Council should be established. This will serve to foster Council's support and elicit feedback on the program. 


\section{9: Establish a Sponsorship Program.}

An effective form of "membership" is to provide for support at different levels as "sponsors." For example, sponsors can contribute time or money, and can designate contributions for a specific project or program. 


\section{Promotion}

According to the National Trust Main Street program, promotion "sells a positive image of the commercial district and encourages consumers and investors to live, work, shop, play and invest in the Main Street district." Promotional activities should foster confidence in the district and encourage activity and investment in the area though advertising, promotional activities, special events, and marketing campaigns. Promotional activities should market the downtown's unique characteristics, activities and business.

\section{Promotion Existing Conditions \& Assets}

Promotion is currently the strongest of the four points in Glenrock. The existing promotional program has numerous motivated volunteers across multiple groups, and several promotional events have already been established by the GDDC.

\section{Existing promotional events include:}

- Craft Fair (GDDC)

- Flea market (GDDC)

- Winterfest (Cooperative efforts between GDDC and the Boys \& Girls Club)

- Downtown Ghost Tour (Historical Commission) 


\section{Promotion Issues}

\section{Location of Events.}

Several of the events are not in the downtown. For many of these events there is no promotional link. Once an event ends out at the parks, there is not a follow-up-activity downtown. This does not mean the events should be located downtown, however the more they tie to downtown the greater the benefit for downtown.

\section{Promotion Opportunities}

\section{Enhancing Existing Programs.}

While new events have been considered, the focus should remain on enhancing the quality of existing programs rather than expanding with entirely new programs.

\section{Recent Programs:}

\section{Ghost Tour.}

The Downtown Ghost Tour that occurred this year was the first of its kind in Glenrock and was a huge success. This program could be expanded to reach more participants and bring people and activity to the downtown.

\section{Deer Creek Days.}

Though not a Main Street program, Deer Creek Days is a large community event. This provides a key opportunity for cross-promotional programs with the downtown. 


\section{Annual Bow Hunt.}

The annual bow hunt brings many out-of-town visitors to the area. This group presents a key marketing opportunity for downtown businesses.

\section{Promotion Actions}

\section{Promotion Coordination.}

P1: Establish Coordinated Events Calendar.

An annual event calendar should be established which includes all the promotional events put on by the numerous groups in Glenrock.

\section{Existing Programs.}

P2: Continue and Enhance the Annual Flea Market.

P3: Continue and Enhance the Annual Crafts Fair.

P4: Continue and Enhance the Winterfest.

P5: Continue and Enhance Downtown Ghost Tour. Cross-Promotional Programs.

P6: Establish a Marketing Strategy for Deer Creek Days Participants.

Establish strategies for cross-promotional marketing and outreach to Deer Creek Days participants.

P7: Establish a Marketing Strategy for Bow Hunt Participants . Establish marketing/outreach strategies for participants in the annual Bow Hunt. 


\section{Design}

According to the National Trust Main Street program, design "means getting Main Street into top physical shape. Capitalizing on its best assets - such as historic buildings and pedestrian-oriented streets - is just part of the story. An inviting atmosphere, created through attractive window displays, parking areas, building improvements, street furniture, signs, sidewalks, street lights, and landscaping, conveys a positive visual message about the commercial district and what it has to offer." Design also includes long-term planning, historic building rehabilitation, good maintenance practices and appropriate new construction.

\section{Design Existing Conditions \& Assets}

\section{Historic Buildings}

The town has many historically significant and potentially significant downtown buildings. These contribute greatly to the character and quality of downtown.

\section{Streetlights and Banners}

The new streetlights and banners create visual interest and design quality in the downtown. The planning and implementation process used to design and install them can be used as a model for future improvement projects.

\section{Commerce Block Building}

The Commerce Block is both a successful rehabilitation project as well as a successful community volunteer effort. The coordinated efforts for the projects planning and implementation provide a model for other similar projects in the 
future. The funding provided by rental income from the building can also be used to support other downtown design projects.

\section{Planters}

The planters provide streetscape beautification and enhance the pedestrian experience in downtown. Their success also provides a model for cooperative downtown design enhancement programs.

\section{Centennial Walkway}

The Centennial Walkway will provide a celebratory design element in the downtown, which is enhanced by its incorporation of public art in its design.

\section{Seasonal Decorations \& Window Displays}

The seasonal holiday decorations and window displays help provide a celebratory aspect to the streetscape and enhance its visual appeal. Their success can be built upon in the future.

\section{Design Issues}

\section{Design Tools}

Currently the tools and policy base for design in downtown Glenrock is very limited. There is one historic resource survey of historic homes, but none for the commercial downtown. There is also no master plan or guidelines for design in downtown. 


\section{Public Infrastructure Improvements}

Little public information-oriented signage exists in town, and wayfinding signage is noticeably lacking. The identification of city parking lots is also insufficient, and it is often unclear to visitors what is and is not a city lot.

\section{Property Improvements}

Several downtown buildings need storefront rehabilitation or more extensive rehabilitation work. Rundown buildings detract from the character of the downtown. There are also several vacant and underdeveloped lots in the downtown which create gaps in the continuity of the streetwall.

\section{Design Opportunities}

\section{Historic Building Rehabilitation}

The many buildings contribute greatly to the character and quality of downtown. Their rehabilitation can significantly enhance the quality and character of the downtown. The success of the recent Commerce Block rehabilitation provides a physical example which may apply to many downtown buildings.

\section{Streetscape Enhancements}

The city recently installed ornamental streetlights and other sidewalk furnishings. These are of high quality and help to establish a distinct identity for the downtown. Further enhancements are needed to promote a walkable, pedestrian environment. These enhancements can build upon the success of streetlights and banners. 


\section{Seasonal Design Elements}

The existing seasonal decorations are distinctive and of good quality. The new window displays have been successful and many business owners are volunteering to participate. Continuance and enhancement of these programs can celebrate and enhance the downtown streetscape.

\section{Design and Technical Assistance Grants}

Design and technical assistance grants are available through the Wyoming Main Street Program. These grants provide for design assistance from registered architects to evaluate a potentially historic property and provide plans or guidance for an appropriate rehabilitation.

\section{Design Actions}

\section{Design Tools:}

\section{D1: Develop Downtown Framework Plan.}

An overall framework plan for downtown improvements should be developed. The plan should include an overall vision for downtown as well as specific streetscape and infrastructure improvements. The extent of streetscape improvements and their location should be determined. Ways to "step down" the intensity of beautification elements for outlying areas, while still conveying a sense of continuity for the downtown overall should be considered. The plan should determine how far these should extend, as well as how the installation may be funded and executed in phases. 


\section{D2: Develop Design Handbook.}

When building owners make improvements, it is important that all rehabilitation be consistent, while recognizing individual needs and tastes. Many communities use a "Design Handbook" as a means of providing advice about appropriate rehabilitation design approaches. A handbook assists property owners in making decisions about how to improve their properties. It can serve as a voluntary guide for owners and also can be used when the Town provides design assistance. The handbook should provide both guidelines for preservation and for appropriate new construction. Examples and/or case studies of façade renovations and appropriate new infill should also be included in the document.

\section{D3: Develop Wayfinding Plan.}

As part of a Wayfinding plan, a series of public signs should be installed that would guide visitors and residents to key downtown resources. These would identify public facilities, parking areas, and also provide a directory to businesses. First, a distinct design should be developed for the sign system, and then a map identifying the key locations should be prepared. This would also include a funding and phasing strategy.

\section{Public Infrastructure Improvements:}

\section{D4: Complete Streetlight Installations.}

Complete the installation of remaining components in the existing streetlight plan. 
D5: Install Wayfinding System.

Install improvements identified in the Wayfinding Plan.

Property Improvements:

D6: Secure Design Assistance Grant(s) for Building Rehabilitations.

Secure design and technical assistance grants for historic property owners desiring to rehabilitate downtown buildings.

D7: Rehabilitate Significant Buildings.

GDDC should provide education and support to property owners undergoing appropriate building rehabilitation projects.

\section{Other:}

D8: Expand Seasonal Decorations and Window Displays Program. 


\section{Economic Restructuring}

According to the National Trust Main Street program, economic restructuring "strengthens a community's existing economic assets while expanding and diversifying its economic base." Economic restructuring programs should begin by supporting existing businesses and markets, and enhancing them to respond to today's consumers' needs. New economic uses should expand upon and be compatible with those characteristics which make the commercial district unique and interesting.

\section{Economic Restructuring Existing Conditions \& Assets}

The primary successful market in Glenrock is staple goods. Other successful businesses include bars and restaurants. Important industries also include shooting, energy, archaeology, and dinosaurs."

\section{Existing Successful Businesses:}

- Grocery Store

- Drug Store

- Hardware store

- Bars

- Restaurants (The Classic)

- Bowling Alley 


\section{Economic Restructuring Issues}

Glenrock lacks a solid economic base in the downtown. Even though there are several well-established businesses, the area overall does not meet its potential. Glenrock is challenged by its close proximity to Casper, in that many goods and services are available there. On the other hand, the unique character of Glenrock can serve as an attraction for Casper residents who may seek a diversion from the city. The small town quality of life also can serve as marketing edge to attract certain businesses. These are business recruitment opportunities that should be studied in more detail. At present, no market study exists that would identify the categories of businesses that might be successful in the area.

\section{Economic Restructuring Opportunities}

A key strategy is to build on the economic assets that do exist. These include energy development companies, shooting sports, and tourism that is attracted to the area by its paleontological resources, including the numerous, nearby dinosaur finds. A market strategy is needed that would identify the best practices for building on these assets, in terms of the downtown.

The Glenrock Economic Development Commission was scheduled to have a strategic planning session in January, 2010. This was a key opportunity for establishing tie-ins between the goals and actions of the GEDC and the Main Street Program. 


\section{Economic Restructuring Actions}

\section{Established Businesses:}

\section{ER1: Establish Business Support Program(s).}

A program focusing on business retention should be established. This program should include strategies for helping established businesses prosper. On-going technical assistance and training programs should be included. This program should be complementary with the tools established in the Market Strategy described below.

\section{Economic Restructuring Tools:}

\section{ER2: Develop an Economic Market Study.}

A market study should identify the types of business that have the potential to succeed in downtown Glenrock.

\section{ER3: Develop a Market Strategy.}

The Market Strategy should focus on downtown and identify actions based on the results of the Market Study. The strategy should identify the best practices for building on existing assets, as well as strategies to take advantage of market opportunities identified in the Market Study. 


\section{Implementation}

\section{Implementation Table}

The following table establishes a five-year, prioritized strategy for the development and implementation of the downtown revitalization program. This table forms an interactive review and monitoring tool for use by the partners in the implementation of the Main Street Program. It is a starting point, and is designed to be easily reviewed and updated as needed throughout implementation of the program.

\section{Categories of Actions}

Actions identified in the body of this report are organized in the table based on the four points of the Main Street Program as described above. Several actions are primarily related to one of the four points, however, many also relate to other points. These related categories are identified in the table.

\section{Implementation Phasing}

The suggested time of implementation for each action is also identified in the table. Several proposed actions are specific to one year, while others are ongoing or cumulative for the full five years.

\section{Key Players}

For each action a primary player involved in its implementation is identified. In many cases supporting players are also identified. 


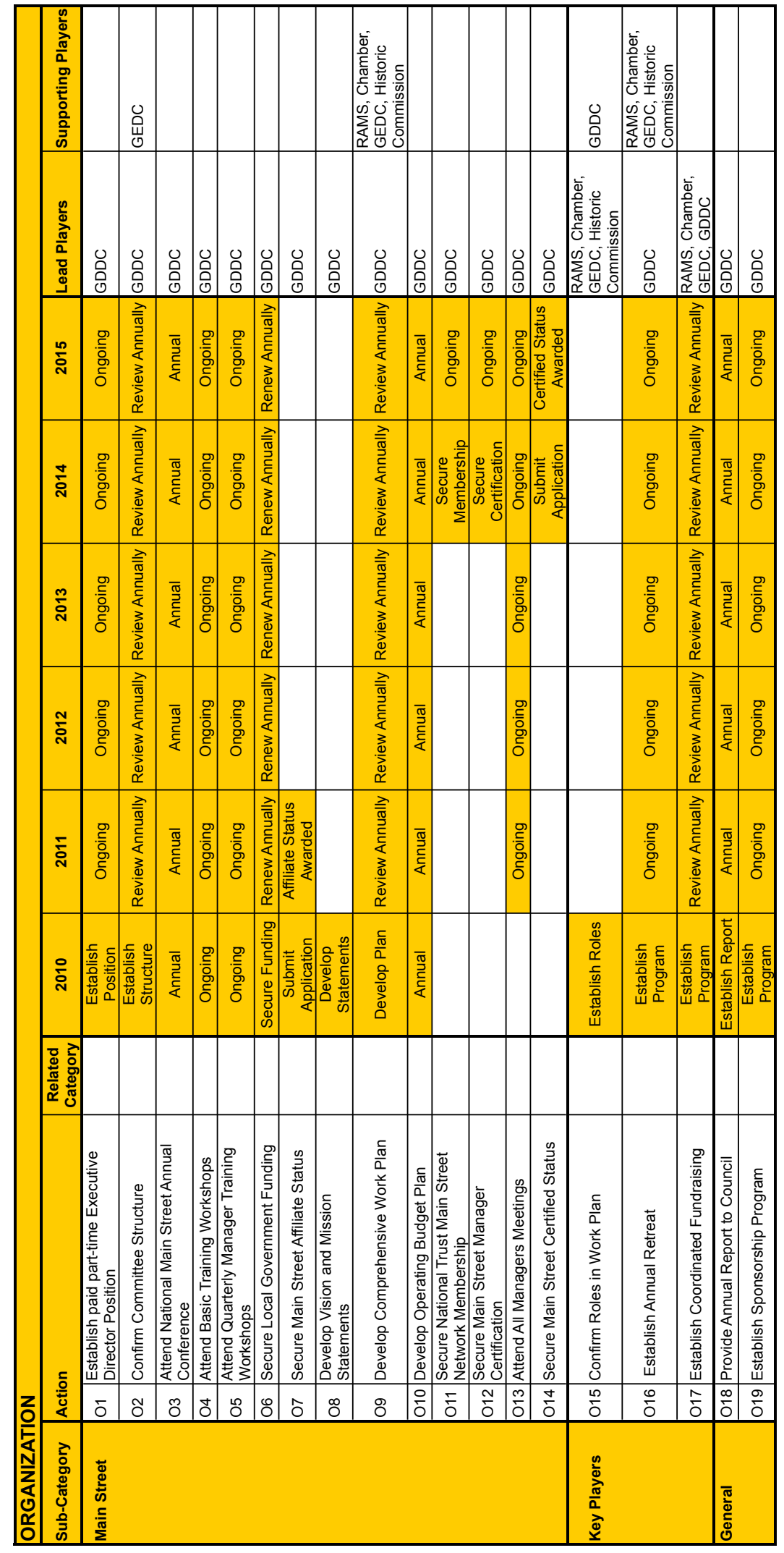

Page 23 

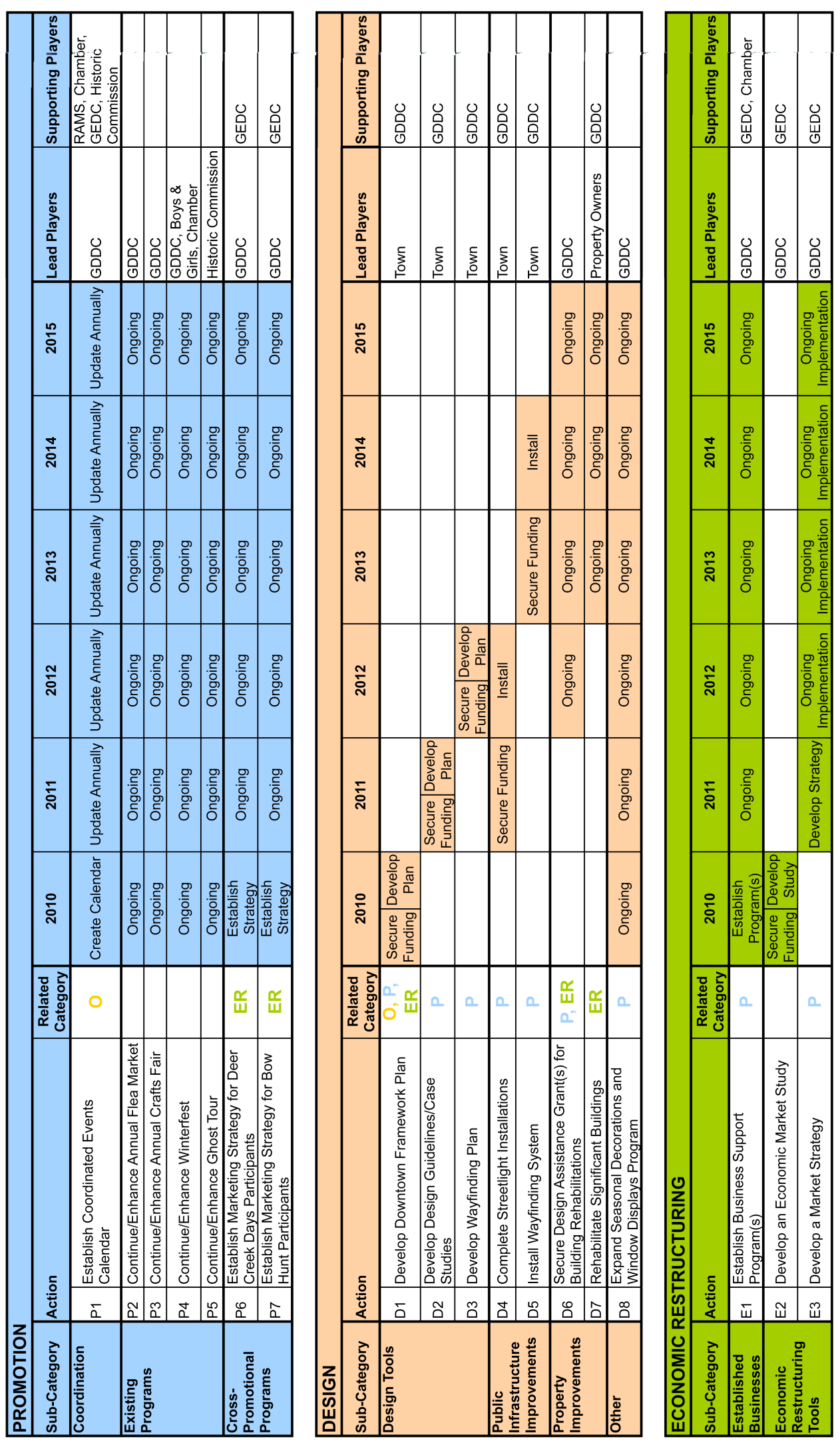

Page 24 


\section{Bibliography}

Supportive literature was predominantly comprised of publications from the National Trust for Historic Preservation (NTHP) Main Street Program. The following section includes an annotated bibliography of the primary literature resources consulted for the project.

National Trust for Historic Preservation (2009). Main Street. About Main Street. Retrieved on November 13, 2009, from http://www.preservationnation.org/main-street/about-main-street/

This NTHP Main Street publication provides an overview of the basics of the Main Street program. It was primarily used as an early source to become familiar with the program and its objectives.

National Trust for Historic Preservation (2009). Main Street. The Eight Principles. Retrieved on November 13, 2009, from http://www.preservationnation.org/mainstreet/about-main-street/the-approach/eight-principles.html

This article provides information of the eight principles that make up the Main Street program; Comprehensive, Incremental, Self-help, Partnerships, Identifying and capitalizing on existing assets, Quality, Change, and Implementation. It was primarily used as an early source to become familiar with the Main Street program and its objectives. The article was also consulted in the establishment of primary goals in the plan to ensure the Strategy Report appropriately represented applicable Main Street techniques.

National Trust for Historic Preservation (2009). Main Street. Getting Started, Using the Main Street Approach. Retrieved on November 13, 2009, from http://www.preservationnation.org/main-street/about-main-street/gettingstarted/

This article provides an outline of the basic steps for starting a Main Street program in a community. This article provided a starting point for some of the programmatic goals for the community. 
National Trust for Historic Preservation (2009). Main Street. Local Main Street Programs. Retrieved on November 13, 2009, from http://www.preservationnation.org/main-street/about-main-street/theprograms/local-programs.html

This article provides information on a recommended structure for a local Main Street Program. It was used primarily for a starting point to establish the program components necessary in the plan.

National Trust for Historic Preservation (2009). Main Street. Local Program Organizational Structure. Retrieved on November 13, 2009, from http://www.preservationnation.org/main-street/about-main-street/theprograms/organizational-structure.html

This article provides detailed tables on two recommended management structures for a local Main Street Program. It was used primarily for a starting point to establish the structural goals in the revitalization plan.

National Trust for Historic Preservation (2009). Main Street. Main Street FAQs, Frequently Asked Questions about the Main Street Approach. Retrieved on November 13, 2009, from http://www.preservationnation.org/mainstreet/about-main-street/the-approach/

This article provides an overview of common features of a local Main Street program and its operation. It was used to create a starting list of questions for the public workshop and strategy sessions to determine how the community wanted their local program to operate.

National Trust for Historic Preservation (2009). Main Street. The Main Street Four-Point Approach. Retrieved on November 13, 2009, from http://www.preservationnation.org/main-street/about-main-street/theapproach/

This article explains the four points of the Main Street approach, established to work together to build a complete community revitalization effort. These four points, Organization, Promotion, Design, and Economic Restructuring, were used as a model for the framework of the Report. This article was also used as an early source to become familiar with the Main Street program's structure and objectives. 